Faculdade de Ciências Econômicas UFRGS
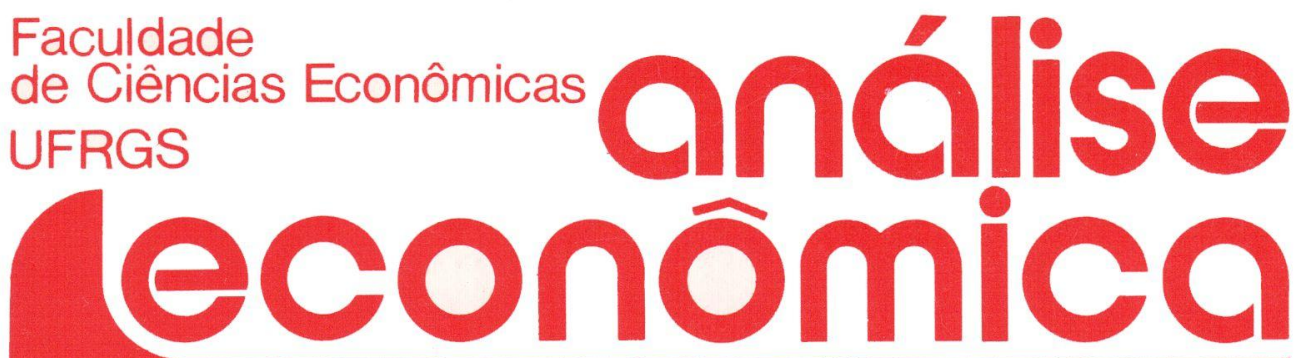

- A LINEAR MOdEL Of BALANCEd GROWTH Joanilio Rodolpho Teixeira Rodrigo Andrés de Souza Penaloza

- TEORIAS ESTRUTURALISTAS DA INFLAÇÃO

Roberto Camps Moraes

- PREÇOS EXTERNOS E EXPÓRTAÇÃO DE MANUFATURADOS Lauro Lobo Burle

- O DESENVOLVIMENTO SUECO Alfredo Marcolin Peringer

- DÉFICIT ENERGÉTICO Fabiano Augusto Nogueira Pinto

- RICARDO E O PROBLEMA SOCIAL Cezar Machado Mello

- UM SABER QUE NÃo SABE: INSTRUMENTO DE PREVISÃO Eleutério F.S. Prado

- SELEÇÃo dE PLANOS DE PRODUÇÃO PARA PEQUENOS PRODUTORES AGRICOLAS Juvir Luiz Mattuella

- PERSPECTIVAS da ECONOMIA do NORDESTE NA DÉCADA DE NOVENTA

Liana Maria da Frota Carleial

- CAIO PRADO JÚNIOR

Pedro Cezar Dutra Fonseca 
UNIVERSIDADE FEDERAL DO RIO GRANDE DO SUL Reitor. Prof. Tuiskon Dick

FACULDADE DE CIÊNCIAS ECONÔMICAS

Diretor: Prof. Walter Meucci Nique

CENTRO DE ESTUDOS E PESQUISAS ECONÔMICAS

Diretor: Reinaldo lgnácio Adams

DEPARTAMENTO DE CIÉNCIAS ECONÔMICAS

Chefe: Prof. Pedro Cezar Dutra Fonseca

CURSO DE PÓS-GRADUAÇÃO EM ECONOMIA

Coordenador: Prof. Nali de Jesus de Souza

CURSO DE PÓS-GRADUAÇĀO EM ECONOMIA RURAL

Coordenador. Prof. Atos Freitas Grawunder

CONSELHO EDITORIAL: Achyles Barcelos da Costa, Aray Miguel Feldens, Atos Freitas Grawunder, Carlos Augusto Crusius, Ernani Hickmann, João Rogério Sanson, Juvir Luiz Mattuella, Maria Imilda da Costa e Silva, Nali de Jesus de Souza, Nuno Renan Lopes de Figueiredo Pinto, Otília Beatriz Kroeff Carrion, Otto Guilherme Konzen, Paulo Alexandre Spohr, Pedro Cezar Dutra Fonseca, Reinaldo Ignacio Adams, Roberto Camps Moraes, Valter José Stülp, Yeda Rorato Crusius, David Garlow (Wharton Econometrics Forecasts Association, E.U.A.), Edgar Augusto Lanzer (UFSC), Eleutério F.S. Prado (USP), Fernando Holanda Barbosa (FGV/RJ), Gustavo Franco (PUC/RJ), Joaquim Pinto de Andrade (UnB), Juan H. Moldau (USP), Werner Baer (Univ. de Illinois, E.U.A.).

COMISSĀO EDITORIAL: Atos Freitas Grawunder, Pedro Cezar Dutra Fonseca, Reinaldo Ignacio Adams e Roberto Camps Moraes.

EDITOR: Nali de Jesus de Souza

SECRETARIA: Maria Ivone de Mello (normalização), Vanete Ricacheski (revisão de textos), Zélide Bregalda (Secretária).

FUNDADOR: Prof. Antônio Carlos Santos Rosa

Os materiais publicados na revista Análise Econômica são de exclusiva responsabilidade dos autores. É permitida a reprodução total ou parcial dos trabalhos, desde que seja citada a fonte.

Aceita-se permuta com revistas congêneres. Aceitam-se, também, livros para divulgação, elaboração de resenhas ou recensōes.

Toda correspondência, material para publicação, assinaturas e permutas devem ser dirigidos ao seguinte destinatário:

PROF. NALI DE JESUS DE SOUZA

Revista Análise Econômica

Av. João Pessoa, 52

90.040 - PORTO ALEGRE (RS), BRASIL

Telefone: (0512) 25-58-44 ramal 33

Fax: (0512) 25-5253 


\title{
A LINEAR MODEL AND ITS PATH OF BALANCED GROWTH
}

\author{
Joanilio Rodolpho Teixeira* \\ and \\ Rodrigo Andrés de Souza Penalozza*
}

\section{INTRODUÇÃO}

In this paper we formalize a linear model of growth where the distinction between investment goods and consumption goods is not established a priori but relies on the type of the demand of the economic agents. We deal with a n-sectoral input-output structure and we show the existence of balanced growth in the context of a dynamic Leontief-type of model closely related to that of DOSSO.

\section{THE GENERALIZED MODEL}

Let $\in$ be an economy with $n$ sectors: $E_{1}, \ldots, E_{\mathbf{i}}, \ldots, E_{n}$. The set $L_{n}=\{1, \ldots, n\}$ denotes the set of natural subindexes from 1 to $n$. Let:

$$
\rho: i_{p} \rightarrow i_{q}, p, q \in L_{n}
$$

be the association rule: " $\mathrm{E}_{\mathrm{i}_{\mathrm{p}}}$ produces capital goods to $\mathrm{E}_{\mathrm{i}_{\mathrm{q}}}$ "; and let

$$
\sigma: i_{r} \rightarrow i_{s}, r, s \in L_{n}
$$

be the association rule: " $\mathrm{E}_{\mathrm{r}}$ produces consumption goods to $\mathrm{E}_{\mathrm{S}}{ }_{\mathrm{s}}$ ".

Let $\Omega(\in)=\left\{E_{1}, \ldots, E_{i}, \ldots, E_{n}\right\}$ be the of all sectors of the economy. Let $I=\left\{i_{1}, \ldots, i_{\alpha}, \ldots, i_{k}\right\} C L_{n}$ be a subset of $L_{n}$ and let

* Department of Economics, University of Brasflia, Brazil.

\begin{tabular}{|l|l|l|l|l|}
\hline ANÁLISE ECONÓMICA & ANO 8 & № 14 & NOVEMBRO/90 & p.3-10 \\
\hline
\end{tabular}


$J=\left\{i_{k}+1, \ldots, i_{\beta}, \ldots, E_{n}\right\} C L_{n}$ be the complement of $I$ in $L_{n}$, with $k \leqslant n$. Let

$$
\begin{aligned}
& \Omega(E, I)=\left\{E_{i_{1}}, \ldots, E_{i_{\alpha}}, \ldots E_{i_{k}}\right\} \\
& \Omega(E, J)=\left\{E_{i_{k}+1}, \ldots, E_{i_{\beta}}, \ldots, E_{i_{n}}\right\}
\end{aligned}
$$

be, respectively, the set of sectors of $\in$ which corresponds to the subset $I$ and the set of sectors of $\in$ which corresponds to J. Given a sector $E_{i} \in \Omega(\in)$ and the association rules, not necessarily injective and/or surjective, the images of $E_{i}$ under $\rho$ and $\sigma$ are, respectively:

$$
\begin{aligned}
& \operatorname{Im} \rho\left(E_{i}\right)=\left\{E_{i_{1}}, \ldots, E_{i_{\alpha}}, \ldots, E_{i_{k}}\right\} \\
& \operatorname{Im} \sigma\left(E_{i}\right)=E_{i_{\alpha_{1}}}, \ldots, E_{i_{\alpha_{\theta}}}, E_{i_{\beta_{1}}}, \ldots, E_{i_{\beta_{\lambda}}} \\
& 1 \leqq \theta \leqq k \\
& k+1 \leqq \lambda \leqq n
\end{aligned}
$$

Then we have the following inequalities:

$$
\begin{aligned}
& \# \operatorname{Im} \rho\left(E_{i}\right)+\# \operatorname{Im}\left(E_{i}\right) \leqslant \# \Omega(\in)+\# \Omega(\in)=2 n \\
& \sum_{i=1}^{n}\left\{\# \operatorname{Im}\left(E_{i}\right)+\# \operatorname{Im}\left(E_{i}\right)\right\} \leqslant \# \Pi(\in)+\pi(\in)=2 n^{2}
\end{aligned}
$$

where \#denotes the cardinality of a countable set and $\mathrm{Il}(\in)$ is the cartesian product $\Omega(\in) \times \Omega(\in)$.

The sectoral product $A_{i}$ of the sector $E_{i}$ is a linear function of the sectoral stock $K_{i}$ of the sector $E_{i}$ :

$$
A_{i}=b_{i} k_{i}, \forall i \in L_{n}
$$

where $b_{i}$ is the sectoral coefficient output/capital of the sector $E_{i}$.

Let $h_{i j}$ be the relative contribution of the production $A_{j}$ of the sector $E_{j}$ to the production $A_{i}$ of the sector $E_{j}$. Furthermore, we define: 


$$
\begin{aligned}
& \gamma_{j}=\underline{\sum_{i=1}^{n} h_{i j}}, \forall j \in L_{n} \\
& F=\left\{\gamma_{1}, \ldots, \gamma_{j}, \ldots, \gamma_{n}\right\}
\end{aligned}
$$

We can see that:

$$
\theta \leqq \min _{j \in L_{n}} \Gamma \leqq \max _{j \in L_{n}} a \leqq 1
$$

Let us suppose that the total output $Y$ as well as the sectoral production $A_{i}$ of the sector $E_{i}$ and its sectoral capital stock $K_{i}$ are continuous functions in relation to the time $t$ and belong to the set:

$$
\Phi_{+} \equiv\left\{f: \mathbb{R}_{+} \rightarrow \mathbb{R}_{+} ; f C^{\infty}\left(\mathbb{R}_{+}\right)\right\}, \mathbb{R}_{+} \equiv[0, \infty] \equiv
$$

of the analytic function from $R_{+}$to $R_{+}$of infinite class. Thus, we have the formal relations of the generalized model:

$$
\begin{aligned}
& Y(t)=\sum_{i=1}^{n} A_{i}(t) \\
& A_{i}(t)=b_{i} K_{i}(t) \quad(i=1, \ldots, n) \\
& \dot{K}_{i}(t)=\frac{d}{d t}\left\{K_{i}(t)\right\}=\sum_{j=1}^{n} h_{i j} A_{j}(t) \quad(i=1, \ldots, n) \\
& \theta \leqslant h_{i j}, \gamma_{j} \leqslant 1(i, j=1, \ldots, n) \\
& b_{i}>\theta \quad(i=1, \ldots, n)
\end{aligned}
$$

The initial condition is:

$$
A_{i}(\theta)=b_{i} K_{i}(\theta) \quad(i=1, \ldots, n)
$$


To solve the model in matrix form, let:

$$
\begin{aligned}
A(t) & =\left[\begin{array}{ll}
A_{1}(t) \\
\vdots \\
A_{n}(t)
\end{array}\right] \\
K(t) & =\left[\begin{array}{ll}
K_{1}(t) \\
\cdot \\
K_{n}(t)
\end{array}\right] \\
B & =\left[\begin{array}{lll}
b_{1} & \\
0 & & \\
H & =\left(h_{i j}\right) & \\
& & \\
H \times n &
\end{array}\right]
\end{aligned}
$$

be, respectively, the vector of sectoral production, the vector of sectoral capital stocks, the diagonal matrix of sectoral output/capital coefficients and the matrix of $h_{i j}$ defined above.

The equations (2.2), (2.3) and (2.6) are now expressed as:

$$
\begin{aligned}
& A(t)=B K(t) \\
& \dot{K}(t)=H A(t)
\end{aligned}
$$

$A(\theta)=B K(\theta)$ or $K(\theta)=B^{-1} A(\theta)$

Substituting (2.11) into (2.12), we have the following system of differential equations:

$$
\dot{K}(t)=H B K(t)
$$

The solution is given by the Taylor series':

$$
K(t)=\left[I_{n}+\sum_{m=1}^{\infty}(H B)^{m} \frac{t m}{m !}\right] K(\theta)
$$

1 See Lancaster (1968) and Woods (1978). 
where $I_{n}$ is the $n \times n$-identity matrix. we have:

Substituting (2.14) into (2.11) and given the initial condition (2.13),

$$
A(t)=B\left[I_{n}+\sum_{m=1}^{\infty}(H B)^{m} \frac{t^{m}}{m !}\right] B^{-1} A(\theta)
$$

We denote by

$$
\text { 1. }\left.\right|_{S}: \Phi^{n} \rightarrow \Phi_{+}
$$

the norm of sum a functional vector in $\Phi^{n}+$. Since $A_{i}(t) \in_{\Phi_{+}}$we have:

$$
Y(t)=|A(t)|_{S}=\sum_{i=1}^{n}\left|A_{i}(t)\right|=\sum_{i=1}^{n} A_{i}(t)
$$

We conclude that the total output of the economy $E$ is given by the equation: ${ }^{2}$

$$
Y(t)=\mid B\left[I_{n}+\sum_{m=1}^{\infty}(H B)^{m} \frac{t^{m}}{m !}\right] B^{-1} A(\theta) I_{s}
$$

\section{BALANCED GROWTH PATH}

Leontief's (1953) own dynamic model of growth produces a balanced path under certain conditions. The model we deal here is not that, but another closely related to DOSSO (1958) and, therefore, of the Leontief-type.

2 In general: $Y(t)=\left|\Omega\left[I_{n}+\sum_{m=1}^{\infty}(H \Omega)^{m} \frac{t^{m}}{m !}\right] \Omega^{-1} A(0)\right|_{s}$

In particular, if $n=2$ and $B$ is the diagonal output/capital coefficient matrix, we have:

$\Omega=\left\{\begin{array}{l}B \Rightarrow \text { Mahalanobis' model } \\ \mathrm{B}^{-1} \Rightarrow \text { Feldman's model }\end{array}\right.$

Such results are presented in Teixeira and Penaloza (1989). 
Equation $\dot{K}(t)=H B K(t)$ may be written in its difference equation form. If we assume that stocks at the beginning of the period $t$ must be sufficient to support the output level $A(t)$ we have:

$$
\Delta K(t) \leqq H B K(t)
$$

To simplify notation let $(H B)=M$, provided that $|H B| \neq \theta$. Therefore:

$$
M \Delta K \leqq K(t)
$$

Suppose now that $\mathrm{H}$ is semi-positive indecomposable with a dominant root less than unit. In consequence of Hawkins-Simon (1949) condition $(I-H)^{-1}$ is an strictly positive matrix. It follows that $M$ is semi-positive indecomposable.

Let us consider the conditions for balanced growth at the

ratio $\mu=\frac{\Delta K_{i}(t)}{K_{i}(t)}$

for $i=1,2, \ldots, n$ and $t=1,2, \ldots, t$. In this case all sectors grow at the same ratio and at least one of then will fully utilize the respective capital capacity. Therefore:

$M \Delta K(t)<\left(\frac{1}{\hat{\mu}}\right) \Delta K(t)$, at least one equality, $K(t) \geqslant \theta$

The only solution of (3.3) is $\frac{1}{\mu^{*}}=\lambda^{*}, K(t)=x^{*}$, where $\lambda^{*}$ and $x^{*}$ are, respectively, the dominant root and its associated characterictic vetor ${ }^{3}$. Such solution gives $\Delta K(t)$ and $K(t)$ for all $t$ since

$$
\begin{gathered}
K(t)=K(t-1)+\Delta K(t-1) \\
\therefore K(t)=\left(1+\mu^{*}\right) K(t-1)=\left(1+\mu^{*}\right)^{t} K(\theta)
\end{gathered}
$$

3 Thus, although we require equilibrium for only one commodity, we in fact obtain it for all, since the solution values give equalities throughout. 
So we have the balanced growth path, provided that $K(\theta)$ is in the same proposition as $X^{\star}$. Since $\lambda^{\star}$ is the Frobenius root the growth rate (which is the inverse of the root) is the smallest. No other growth path of this kind, however, have associated nonnegative stock vectors. On the other hand, if there are surpluses everywhere we have:

$$
M \Delta K(t)\langle\langle(1 / \hat{\mu}) \Delta K(t)
$$

In such situation, since $\Delta K(t) \geqslant \theta$, we can find some strictly positive matrix $R$ such that $(M+R) \Delta K(t) \leqslant(1 / \hat{\mu}) \Delta K(t)$, at least for one equality. The solution is $1 / \hat{\mu}_{M}=\mu^{*}(M+R)$ where $\lambda^{*}(M+R)$ denotes the Frobenius root associated with $(M+R)$. It happens that both $M$ and $(M+R)$ are semi-positive indecomposable matrices with $(M+R)>>M$, so that $\left.\lambda^{*}(M+R)\right\rangle \lambda^{*} M$ and $\hat{\mu}\langle\mu$. Therefore the rate of balanced growth with surplus stocks is less the balanced equilibrium growth rate $\mu^{*}$.

\section{BIBLIOGRAFIA}

DORFMAN, R., SAMUELSON, P. \& SOLOW, R. Linear Programming and Economic Analysis. Mc Graw-Hill, 1958.

LANCASTER, K. Mathematical Economics Mac Millan Co, 1968.

LEONTIEF, $W$ Studies in the Structure of the American Economy Oxford University Press, 1953.

TEIXEIRA, J. \& PENALOZA, R. Linear Generalization of the Feldman Mahalanobes Model. Proceedings of the 1989 Brazilian Meeting of Econometrics. SBE Editores, v. 1, 1989.

WOODS, J. Mathematical Economics. Longman Group Ltda., 1978.

\section{SINOPSE}

\section{UM MODELO LINEAR E SEU CAMINHO DE CRESCIMENTO EQUILIBRADO}

Neste artigo formaliza-se um modelo linear de crescimento onde a distinção entre bens de investimento e bens de consumo não é estabeleci- 
da, a priori, mas baseia-se no tipo de demanda dos agentes econômicos. Usa-se uma estrutura de insumo-produto com $n$ setores e mostra-se a existência de crescimento balanceado no contexto de um modelo dinâmico fechado tipo Leontief, semelhante ao abordado por DOSSO. 